\title{
DIAGNOSIS AND MANAGEMENT OF A FISH BONE FOREIGN BODY AT ESOPHAGEAL INTROITUS WITH AND WITHOUT RETROPHARYNGEAL ABSCESS
}

\author{
Ade Asyari, Novialdi, Fachzi Fitri, Yolazenia
}

\begin{abstract}
Abstrak
Benda asing yang tertelan merupakan kegawatdaruratan di bidang telinga hidung tenggorok (THT). Tulang ikan merupakan salah satu benda asing di tenggorok yang banyak ditemukan. Abses retrofaring merupakan komplikasi yang sering terjadi akibat tersangkut benda asing ini. Foto polos leher posisi lateral perlu dilakukan untuk kecurigaan adanya lesi di daerah faring. Pasien dengan gejala menetap harus dievaluasi dengan endoskopi, walaupun pada pemeriksaan radiologi tidak tampak. Benda asing harus segera dikeluarkan untuk mencegah komplikasi lebih lanjut. Abses retrofaring diterapi dengan medikamentosa dan drainase pus. Jika terdapat benda asing harus dikeluarkan. Dilaporkan dua kasus benda asing tulang ikan di introitus esofagus. Kasus pertama pada seorang pasien laki-laki umur 42 tahun tanpa abses retrofaring dan kasus kedua pada anak laki-laki berusia 8 tahun dengan abses retrofaring. Tulang ikan terlihat pada ronsen foto leher jaringan lunak posisi lateral. Pada kedua pasien dilakukan esofagoskopi untuk mengambil tulang ikannya dan pada pasien kedua dengan abses retrofaring, absesnya sudah pecah dan pus didrainase dikombinasikan dengan pemberian antibiotik intravena.
\end{abstract}

Kata Kunci: benda asing, tulang ikan, abses retrofaring, esofagoskopi

\section{Abstract}

Foreign body ingestion is an emergency in otorhinolaryngology. One of the most common ingested foreign body is a fish bone. Retropharyngeal abscess is well-documented complication from foreign body ingestion. The soft tissue neck radiograph lateral position is the most significant radiologic examination performed in a patient with a suspected pharyngeal lesion. In patient with persistent symptoms should be evaluated with endoscopy, although radiological examination was negative. We have to extract foreign body immediately to prevent further complication. Retropharyngeal abscess should be treated with medical and drainage of pus. If there is a foreign body must be removed. Two cases of a fish bone foreign body at esophageal introitus was reported. First case in 42 year-old male without retropharyngeal abscess and second case in 8 year-old boy with retropharyngeal abscess. Fish bones were seen from lateral neck soft tissue $x$-ray. Esophagoscopy were performed to removed fish bones and in the second patient, the abscess had ruptured and the pus was drainage as the treatment combined with intravenous antibiotic.

Key Words: foreign body, fish bone, retropharyngeal abscess, esophagoscopy

Authors affiliation: Bagian Telinga Hidung Tenggorok Bedah Kepala \& Leher, Fakultas Kedokteran Universitas Andalas/RSUP Dr.M.Djamil Padang. Correspondence: Ade Asyari, Bagian Telinga Hidung Tenggorok Bedah Kepala \& Leher, Fakultas Kedokteran Universitas Andalas/RSUP Dr.M.Djamil Padang, JI. Perintis Kemerdekaan No.94 PO Box 49 Padang 25127, telp/fax: 0751-37194, email: adeasyari2@gmail.com 


\section{INTRODUCTION}

Patients ingested foreign bodies are often found to come to the emergency service of otorhinolaryngologist. Ingestion foreign body is often found in both children and adults. ${ }^{1,2}$ Approximately $80-90 \%$ cases of foreign body ingested through the gastrointestinal tract and pass spontaneously, $10-20 \%$ need non-surgical treatment (endoscopic), and $1 \%$ need surgical treatment. $^{1-5}$

The most common clinical symptoms of ingested foreign bodies are pharyngeal pain, odynophagia, dysphagia, foreign body sensation, and hypersalivation. Older children and adults may identify the ingestion and localize area of discomfort. However, the area of discomfort often does not correlate with the site of impaction. ${ }^{1}$ One of the most common foreign body ingestion is a fish bone..$^{1-5}$

Most cases swallowed fish bone can be identified and removed by direct action. This is due because mostly fish bones lodge in the oropharynx (such as the tonsils, base of the tongue, vallecula, and pyriform sinus). ${ }^{5}$ When the fish bones can not be identified directly because it impaction occurs at less common site such as the cricopharynx or cervical esophagus, radiological examination is needed to determine the location of foreign bodies. Plain radiograph of soft tissue neck lateral position is the first choice for that case. ${ }^{6}$ In patient with persistent symptoms should be evaluated with endoscopy, although radiological examination was negative. $^{7}$

Foreign bodies can cause damage to the pharynx and esophagus and cause complications such as esophageal perforation, ${ }^{8}$ retropharyngeal abscess and / or mediastinitis. ${ }^{1,9,10}$ Harkani et $\mathrm{al}^{11}$ reported 5 cases of retropharyngeal abscess which 3 cases were caused by stuck a fish bone.

With the extensive use of antibiotics for upper respiratory tract infections, retropharyngeal abscess is increasingly rare. However, mortality from complications arising from retropharyngeal abscess is still high enough, so that early diagnosis and proper treatment are extremely need. ${ }^{10-15}$

Management of retropharyngeal abscess conducted medical and operative treatment. Retropharyngeal abscess incision can be performed either intra-oral or external approach depends on the extention of the abscess. When the abscess caused by trauma of foreign bodies, the foreign bodies should be sought and extracted. Retropharyngeal abscess generally have a good prognosis with early diagnosis and proper treatment so that the complications do not happen. ${ }^{10-15}$

\section{CASE PRESENTATION}

\section{First Case}

A 42-year old male patient came to emergency room Dr.M.Djamil Hospital Padang on November 21 $1^{\text {st }}, 2015$ with chief complain pain in swallowing since 2 days before admission. Previously patient was eating rice with roasted fish, suddenly he felt a fish bone stuck in his throat. There was no effort to pull out the foreign body. There was no neck stiffness, no fever, no difficulty in breathing, no hoarsness. There was no swelling at the neck. There was no pus came out from the mouth. There was no 
history of diabetic. Patient work as civil servant.

On physical examination general condition was moderately ill, composmentis cooperative, blood pressure $120 / 80 \mathrm{~mm} \mathrm{Hg}$, heart rate $88 \mathrm{x} / 1 \mathrm{~min}$, respiratory rate $20 \mathrm{x} / \mathrm{min}$, temperature $36.8^{\circ} \mathrm{C}$. On ear and nose examination there was no abnormality was detected. On throat examination there was not seen any foreign body (a fish bone), there was no protude of posterior pharyngeal wall. Indirect laryngoscopy there was not seen any foreign body.

On lateral neck $x$-ray, there was opaque foreign body appearance elongated at soft tissue retrolarynx as high as C6. There was mild thickness $(18 \mathrm{~mm})$ at retrolarynx (figure 1).

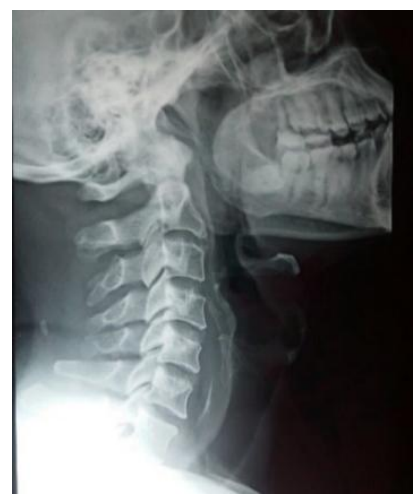

Figure 1. Lateral Neck x-ray show radioopaque foreign body appearance as high as $\mathrm{C} 6$ with mild thickness at retrolarynx soft tissue

Patient was diagnosed with suspected a fish bone foreign body at esophageal introitus and planned to performed diagnostic and therapeutic esophagoscophy under general anesthesia. After informed consent patient was aggreed and performed laboratory examination, electrocardiograph (ECG), thorax x-ray, consult to Internal Medicine Department and Anesthesiology Department for operating and anesthesia tolerance.

Laboratory examination was in normal limit. On ECG and thorax x-ray there was no abnormality was detected. Esophagoscophy using rigid esophagoscope was done under general anesthesia. A fish bone (figure 2) was successfully remove from esophageal introitus (17 cm from incisivus teeth).

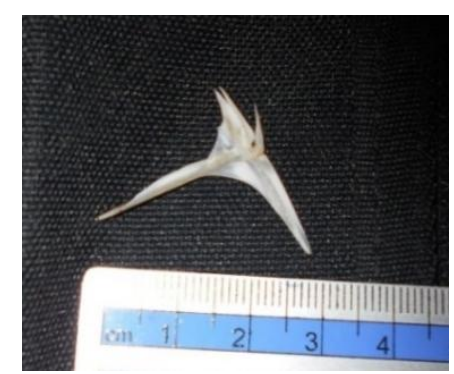

Figure 2. A fish bone

Post operation patient was inward and give therapy cefoperazone injection $2 \times 1$ gram (iv) and dexamethasone $3 \times$ $5 \mathrm{mg}$ (iv). Follow up on second day after operation there was no complain from the patient. Patient was discharged home and give therapy: dexamethasone $3 \times 0.5 \mu \mathrm{g}$, ciprofloxacin $2 \times 500 \mathrm{mg}$, and suggest to control to outpatient clinic. Follow up on fifth and tenth day after operation, there was no complain and no abnormality was detected from the patient.

\section{Second Case}

A 8 year-old boy was brought by his mother to emergency room Dr.M. Djamil Hospital Padang in December $12^{\text {nd }}, 2015$ with chief complain neck stiffness since 1 day before admission. Previously patient was eating with a fish, 
suddenly he felt a fish bone stuck at the throat 3 days ago. He tried to pull out by scratching with finger but a fish bone still felt stucked. There was pain and difficulty in swallowing after the incident. There was muffled voice and difficulty in opening the mouth since 1 day ago. There was fever, hypersalivation, and back stiffness since 1 day ago. There was swelling and pain at the right side of the neck. There was no difficulty in breathing, no hoarsness. There was no pus came out from the mouth. There was no history of diabetic.

On physical examination general condition was moderately ill, composmentis cooperative, blood pressure $110 / 70 \mathrm{~mm} \mathrm{Hg}$, heart rate $90 \mathrm{x} / 1 \mathrm{~min}$, respiratory rate $20 \mathrm{x} / \mathrm{min}$, temperature $38^{\circ} \mathrm{C}$. On ear and nose examination there was no abnormality was detected. On oral cavity examination there was trismus $1 \mathrm{~cm}$, throat could not be evaluated. On neck examination there was neck stiffness, torticollis and there was swelling at the right side, solid, tenderness, no fluctuative (figure 3 ).

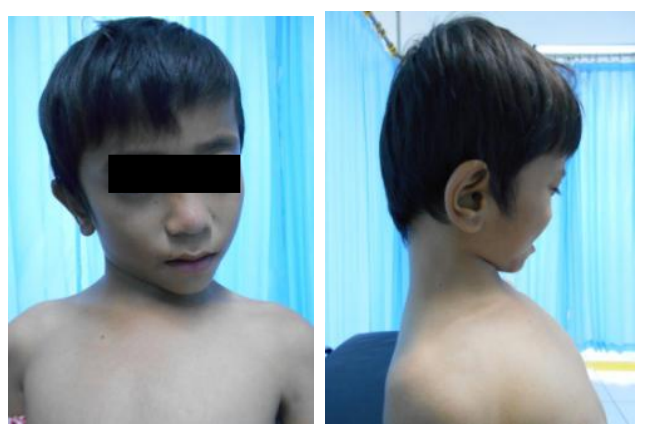

\section{Figure 3.Picture of the patient showing torticollis}

On lateral neck $x$-ray there was opaque appearance at soft tissue retrolarynx as high as C6. There was thickness at retropharynx $15 \mathrm{~mm}$. From anteroposterior view showing the trachea shift to the left (figure 4).

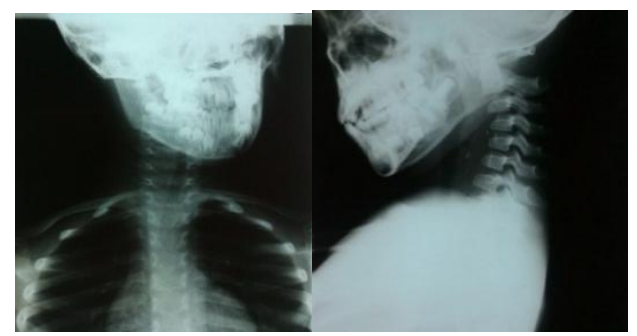

Figure 4. First neck x-ray (lateral and anteroposterior view) showing thickness at retropharynx and radioopaque appearance (suspect a fish bone) as high as $\mathrm{C6}$ and trachea shift to the left

On laboratory examination found:

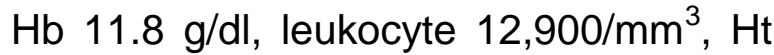
$38 \%$, thrombocyte $258,000 / \mathrm{mm}^{3}$, PT 10.3 second, APTT 35.6 second. Conclusion: leukocytosis.

Patient was diagnosed with suspected retropharyngeal abscess + neck region cellulitis caused by suspected a fish bone foreign body at esophageal introitus. Patient was planned to performed aspiration, incision and exploration of abscess + diagnostic and therapeutic esophagoscophy under general anesthesia. Patient was given therapy: cefoperazone $2 \times 1$ gr (iv), metronidazole $3 \times 250 \mathrm{mg}$ (iv), dexamethason $3 \times 3 \mathrm{mg}$ (iv) and paracetamol $3 \times 250 \mathrm{mg}$ (orally). Tredelenburg position. After informed consent patient's family was aggreed and we consulted to Pediatric and Anesthesiology Department for operating and anesthesia tolerance.

While waiting in preoperation room after we gave therapy, patient felt better, pain was decrease and patient 
could open the mouth widely. On throat examination there was no protude of posterior pharyngeal wall. Before take to the operation room, neck $\mathrm{x}$-ray was repeated (figure 5).

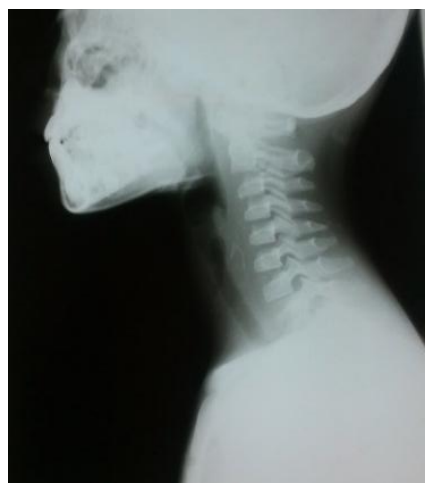

Figure 5. Second neck $x$-ray before to operation room showing the thickness at retropharynx and opaque appearance (suspect a fish bone) as high as C5-6

Esophagoscopy using rigid esophagoscope was done under general anesthesia. We found pus came out as high as $13 \mathrm{~cm}$ from incisivus (at the level of cricopharynx), pus was suctioned, a fish bone was seen. A fish bone (figure 6) was successfullly extracted using alligator forcep. Pus was drainaged maximally by pressing the swelling at the neck.

Post operation patient was inward and give therapy cefoperazone $2 \times 1 \mathrm{gr}$ (iv), metronidazole $3 \times 250 \mathrm{mg}$ (iv), dexamethasone $3 \times 3 \mathrm{mg}$ (iv), and paracetamol $3 \times 250 \mathrm{mg}$ (po).

Follow up on first day after operation there was no pain in swallowing, no neck stiffness, no difficulty in breathing, no chest pain. Swelling at the neck was decreased. On physical examination on throath and chest there was no abnormality was detected. At right neck region: the swelling was decreased, no fluctuative. Therapy was continued.

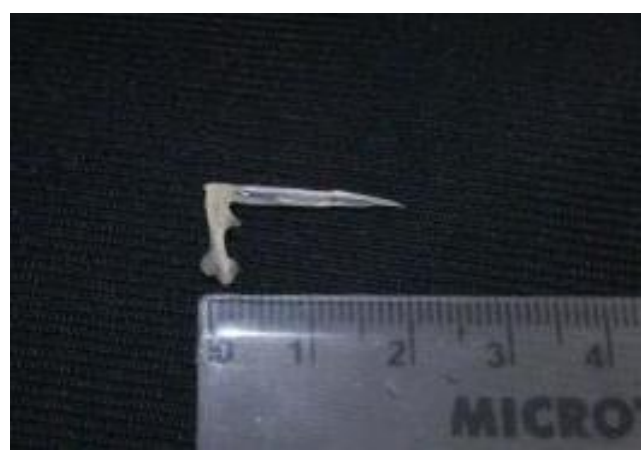

Figure 6. A Fish Bone

Follow up on the eight day after operation, there was no fever, no pain in swallowing, patient could eat and drink normally, no neck stiffness, no chest pain, no difficulty in breathing. On physical examination on throat and chest there was no abnormality was detected. From culture and sensitivity test of the pus was found: Klebsiella spp, and sensitive with chloramphenicol, cefotaxime, gentamycin, ciprofloxacin, ceftriaxone, ceftazidime, cefoperazone, meropenem, fosfomycin, and levofloxacin. Patient was discharged home and gave therapy: paracetamol $3 \times 250$ $\mathrm{mg}$, chloramphenicole $4 \times 250 \mathrm{mg}$ and advice to control to outpatient clinic.

Follow up on two weeks after operation, there was no fever, no pain in swallowing, patient could eat and drink normally, no neck stiffness, no chest pain, no difficulty in breathing. On physical examination on throat and chest there was no abnormality was detected. On neck region there was minimal edema, solid, no hyperemic, no fluctuative and no tenderness. Patient advice to control to outpatient clinic in 1 week later. 
Patient did not control again to M.Djamil Hospital after that because of economic reason when we called on January $22^{\text {nd }} 2016$, his mother said that his son there was no complain and there was no swelling at the neck anymore. Patient controlled to district hospital on January $28^{\text {th }}, 2016$ (6 weeks after operation), there was no complain and no abnormality was detected from the patient.

\section{DISCUSSION}

It has been reported two cases of a fish bone foreign body at esophagus at the level of cricopharynx (esophageal introitus). In the first case, patient was a 42 year-old man and the second case was a 8 year-old boy. A fish bone foreign body is the most found foreign body ingestion in adults. ${ }^{1-5}$ Chiu et $a^{26}$ found $79.8 \%$ of foreign bodies in the throat were fish bones, and Shaariyah et a ${ }^{\beta}$ found fish bones in $44,3 \%$ of foreign body ingestion. Sung et $a t^{4}$ evaluated 316 cases of swallowed foreign bodies and found 169 male patients (53.5\%), 147 female (46.5\%), with an average age of 47.9 years (range 2 months to 87 years). There are a variety of age in the case of swallowing foreign bodies.

Patients who ingested foreign bodies can show varies clinical symptoms such as the presence of a foreign body sensation, dysphagia, odynophagia, chest pain, hypersalivation, or vomiting. Odynophagia is the most common symptom found in adults and cause them to come to hospital. ${ }^{3}$ This is consistent with symptoms that found in first patients. In the second case because there was retropharyngeal abscess complications, patient chief complain was neck stiffness beside there was fever, odynophagia and hypersalivation.

Based on multivariate analysis performed by Marcal et al swallowed a fish bone, short symptoms ( $<6$ hours) and symptoms at or above the cricoid cartilage is an independent variable that predicts the success of the removal of foreign bodies are ingested. Patients who ingested fish bone has a higher success rate than any other foreign bodies in the expenditure of foreign bodies. This may be due to fish bone often caught in oropharynx. ${ }^{1}$ In patients, the location of fish bones were at the esophagus at the level of cricopharynx causing fish bones are not found on examination of the oropharynx and larynx, and needs to perform esophagoscopy to view the location and retrieval of the fish bones. Cricopharynx is the narrowest part of the esophagus. ${ }^{16}$ The most common site of fish bone impaction in the esophagus is the cervical esophagus at the level of the cricopharynx. $^{5}$

Plain radiography of soft tissue neck lateral position is a supporting examination in the diagnosis of a foreign body in the throat and in the case of a retropharyngeal abscess. Some literatures report the accuracy of the figures varied, and seems to depend on fish bones radiodencity. ${ }^{6}$ Shaariyah et $a^{\beta}$ discovered $19.4 \%$ of fish bones fail visible on plain radiography. On plain neck radiography lateral position on both patients, we could see the radiopaque appearance as high as C6 that believed to be a fish bone. It is important to note that not all calcifications in the plain radiograph represent foreign bodies. Calcified normal structures, like the 
thyroid, arytenoid and cricoid cartilages, styloid process and stylohyoid ligament, osteophytes and ossification of anterior longitudinal ligament, can mimic abnormal radioopaque foreign bodies. Knowledge of the anatomy is crucial when interpreting the plain $\mathrm{x}$-rays. ${ }^{17}$

Patients with suspected of swallowing sharp foreign bodies such as fish and chicken bones, paper clips, toothpicks, needles, and wire dentures should be evaluated to determine the location of foreign bodies. Many of sharp foreign bodies are not visible on radiological examination, then requiring endoscopic examination. The option to take a foreign body at or above cricopharynx is using direct laryngoscopy, if not managed or foreign body is under cricopharynx, rigid or flexible endoscopy can be performed. Rigid and flexible endoscopes have a number of similar success and morbidity. Flexible endoscopes are more effective because it can be done in the clinic, without general anesthesia, but if there is a stick or sharp foreign body, rigid endoscopy is necessary. Rigid endoscopes having a larger lumen making it possible to see the whole part of foreign body an be able to take foreign body with direct view that decrease the risk of laceration of the mucosa. ${ }^{18,19}$ In these patients, foreign bodies are not visible from the examination of indirect or direct laryngoscopy, but was seen from radiologic examination. We performed rigid esophagoscopy to make sure and extracted the foreign body (a fish bone).

Ingestion of a fish bone may cause mucosal ulceration and inflamemation. It could lead to esophageal perforation and make consequences such as retropharyngeal abscess, mediastinitis, aortoesophageal fistula. ${ }^{20}$ Retropharyngeal abscess is now rarely found along with increased use antibiotic therapy. ${ }^{10}$ Retropharyngeal abscess mostly occur in children. This because in general, the source of infection in retropharynx space comes from the infection in the nose, adenoid, nasopharynx and paranasal sinuses, which spread to retropharynx lymph nodes called nodes of Rouvier. The gland is usually atrophy at the age of 5 years. Beside spreads from contiguous area affecting the retropharyngeal nodes, retropharyngeal space could be infected because of inoculated directly secondary to a penetrating foreign body like a fish bone as we observed at the second patient, and through oropharyngeal injuries such as accidental laceration or iatrogenic causes. ${ }^{10}$

Only few cases of retropharyngeal abscess have visible swelling of posterior pharynx on physical examination. X-ray examination is useful in the diagnosis of retropharyngeal abscess. Wholey (quoted from 12-15) conclude about the space of retropharynx on plain neck radiography lateral position that when in children and adults found retropharynx (as high as $\mathrm{C} 2$ vertebrae) size more than $7 \mathrm{~mm}$, the retrotracheal (as high as C6 vertebrae) size in children over $14 \mathrm{~mm}$ and in adults over $22 \mathrm{~mm}$, it is suspected there is pathologic process in retropharynx space. ${ }^{12-15}$ From the examination of plain radiography of the neck lateral position in the first patient appears mild thickness in retropharynx area as high as C4-C7 so we suspected there was just inflammation at retropharnx space. In the second patient there was a thickness as high as $\mathrm{C} 4-\mathrm{C} 7$, $15 \mathrm{~mm}$ in size, so we suggest there was 
retropharyngeal abscess. The diagnosis was consistent with clinical presentation.

Management of retro pharyngeal abscess should be done as soon as possible which includes: release of the airway, antibiotics, fluid replacement, incision and drainage of an abscess that can be done with intraoral or external approach. If there is a foreign body must be removed immediately. ${ }^{10-15}$ In the first case there was no signs of retropharyngeal abscess. In the second case when evaluating using esophagoscope there was pus came out as high as 13 $\mathrm{cm}$ from incisivus, the pus was drainaged maximally and foreign body was extracted.

In the second case there was swelling at right side of the neck. We suggest this because of the fish bone impacted at the right side and made retropharyngeal abscess especially at the right side. Because of retropharynx consist of loose connective tissue and under the forces of gravity and pressure in the sorrounding tissues tend to move towards planes of least resistance, ${ }^{21}$ and make inflammation spread to the right soft tissue of the neck until subcutaneus. After we drainaged the pus in operating room, the swelling was decreased.

Lai et $a f^{22}$ and Poon et $a f^{23}$ reported when patient present $>2$ days after foreign body ingestion, positive finding on the lateral neck x-ray, impaction of the foreign body at the level of the cricopharynx as risk factors for complication. Sung et a/ ${ }^{4}$ reported beside duration of impaction, the type and size of the foreign bodies were significant independent risk factors associated with the development of complication in patient with ingestion foreign body. Patient with immunocompromise like diabetes mellitus, malignancy, chronic alcoholism and acquired immunodeficiency syndrome (AIDS) are reported causes of retropharyngeal abscess in adults. ${ }^{24}$ In the first case there was no retropharyngeal abscess as complication. This might be because the duration was not more than 2 days and patient was an immunocompetent adult, although positive radiological finding and impaction of foreign body at the level of the cricopharynx. Unlike prior study, Sung et $a t^{4}$ reported that radioopacity was not significantly associated as a risk factor for complication. ${ }^{4}$ In the second case the duration was more than 2 days and the patient was a child that has lower immunity than an adult so retropharyngeal abscess was developed as complication.

\section{CONCLUSION}

Swallowed or lodged foreign bodies commonly found in both children and adult. The common ingested foreign body is a fish bone. Retropharyngeal abscess is a complication that often occurs due to swallowed foreign bodies. Plain radiographs of the neck lateral position needs to be done for suspicion of a lesion in the pharynx. if there are persistent symptoms needs to be done diagnostic and therapeutic endoscopy although radiologic examination was negative. Foreign bodies should be removed to prevent further complications.

\section{REFERENCES}

1. Marcal N, Soares JB, Pereira G, Guimaraes J, Goncalves M, Godinho T. The management of ingested foreign 
bodies in ear, nose, and throat emergency unit: prospective study of 204 cases. Acta Otorrhinolaringol Esp 2013;64(3):197-203.

2. Ambe P, Weber SA, Schauer M, Knoefel WT. Swallowed foreign bodies in adults. Dtsch Arztebl Int 2012;109(50):869-75.

3. Shaariyah MM, Goh BS. Retrospective review of surgical management of foreign body ingestion. Med $\mathrm{J}$ Malaysia 2009;64(4):307-10.

4. Sung $\mathrm{SH}$, Jeon SW, Son HK, Kim SK, Jung $\mathrm{MK}$, Cho $\mathrm{Cm}$, et al. Factor predictive of risk for complications in patients with oesophageal foreign bodies. Digest Liver Dis 2011;43:632-5.

5. Kim JP, Kwon OJ, Shim HS, Kim RB, Kim JH, Woo SH. Analysis of clinical feature and management of fish bone ingestion of upper gastrointestinal tract. Clin Exp Otorhinol 2015;8(3):261-7.

6. Shetty D, Gay DAT. The lateral neck radiograph for an impacted fish bone in the aero-digestive tract: going back to basics. J Biomed Sci Eng 2012;5:826-8.

7. ASGE. Management of ingested foreign bodies and food impaction. Gastrointest endosc 2011;73(6):1085-91.

8. Chiu HH, Li JH, Chen JS. Penetration of esophageal wall by a fish bone. J Intern Med Taiwan 2006;17:298-301.

9. Ramos HF, Takahashi MT, Monteiro TA, Koisbi HU, Imamura R. Late evolution retropharyngeal abscess after ingestion of foreign body. Intl Arch Otorhinolaryngol 2009; 13(3):346-9.

10. Afolabi OA, Fadare JO, Oyewole EO, Ogah SA. Fish bone foreign body presenting with an acute fulminating retropharyngeal abscess in a resourcechallenged center: a case report. J Med Case Reports 2011;5:1-5.

11. Harkani A, Hassani R, Ziad T, Aderdour $L$, Nouri $\mathrm{H}$, Rochdi $\mathrm{Y}$, et al. Retropharyngeal abscess in adults: five case reports and review of the literature. Sci World J 2011;11:1623-9.
12. Gadre AK, Gadre KC. Infections of the deep spaces of the neck. In: Bailey BJ, Johnson JT,editors. Head \& neck Surgery Otolaryngology. $4^{\text {th }}$ ed. Philadelphia: Lippincott Williams \& Wilkins;2006. p.665-82

13. Al Sabah B, Salleen H, Hagr A, Rosen JC, Manoukian JJ, Tewfik TL. Retropharyngeal abscess in children: 10year study. J. Otolaryngol 2004;33(6):352-5.

14. Sharma SB, Hong $P$. Ingestion and pharyngeal trauma causing secondary retropharyngeal abscess in five adults patients. Case Reports in Emerg Med 2012;1:1-5.

15. Wang Y, Sigh N, Mernagh J. Retropharyngeal abscess: its evolution and imaging assessment. OMICS J. Radiology 2013;2(5):1-3.

16. Viswanatha B. Esophagus anatomy. Diakses dari: http://www.emedicine.medscape.com/arti cle/1948973-overview

17. Hajiioannou J, Kousoulis P, Florou V, Stavriandu E, Moshovakis E, Anagnostou $E$ latrogenic migration of an impacted pharyngeal foreign body of the hypopharynx to the prevertebral space. Otorhino laryngol Head and Neck Surg 2011;43:30-4.

18. Shivakumar AM, Naik AS, Prashanth KB, Hongal GF, Chaturvedy G. Foreign bodies in upper digestive tract. Indian $\mathrm{J}$ Otolaryngol Head and Neck Surg 2006;58(1):63-8.

19. Ekim H. Management of esophageal foreign bodies: a report on 26 patients and literature review. Eastern $\mathrm{J}$ Med 2010;15:21-5.

20. Nourizadeh N, Irani S, Soroori A. Fish bone ingestion: a case report of a unique route of extraction. Arch Iran Med 2013;16(9):555-6.

21. Al-Shukry SM. A swallowed fishbone penetrating the oesophagus into the sternomastoid muscle. SQU J Sci Research: Med Sci 2003;5:51-2. 
22. Lai AT, Chow TL, Lee DT, Kwok SP. Risk factors predicting the develompment of complications after foreign body ingestion. $\mathrm{Br} J$ Surg 2003;90:1531-5.

23. Poon T, Yuen C, Fung K. Predictive risk factors for complications following fish bone ingestion. HK Pract 2007;29: 3749.

24. Chu FKC. Retropharyngeal abscess. Hong Kong J Emerg Med 2002;9(3):1657. 